\section{Comment}

Contact partners of women with $C$ trachomatis infection may be deterred from seeking medical help because of the intimate nature of the infection and because a urethral swab is needed. Urine samples obtained at home provide a non-invasive and less time consuming alternative.

A similar procedure for contact tracing of female partners of men infected with $C$ trachomatis should be considered as the organism has been detected in urine samples from women. ${ }^{5}$

We thank the participating general practitioners.

Contributors: BA coordinated the primary study hypothesis and the core ideas, designed the protocol, obtained approval from the ethics committee, coordinated inclusion of patients, scanned the data, and coordinated the interpretation of results and writing of the paper. $L \varnothing$ discussed the primary hypothesis, core ideas, analysis, and protocol design and participated in the interpretation of results and writing of the paper. JKM discussed the hypothesis and ideas, led the analysis of the samples obtained, participated in the interpretation of results, and edited the paper. FO discussed the hypothesis and core ideas and participated in the protocol design, coordination of contact with the general practitioners, the interpretation of results, and the writing of the paper. FO is the guarantor of the paper.

DAK

Funding: University of Aarhus, Denmark and Nycomed

Conflict of interest: None.

Cates W Jr, Wasserheit JN. Genital chlamydial infections: epidemiology and reproductive sequelae. Am J Obstet Gynecol 1991;164:1771-81.

2 Ripa T. Epidemiologic control of genital Chlamydia trachomatis infections. Scand J Infect Dis Suppl 1990;69:157-67.

3 Jaschek G, Gaydos CA, Welsh LE, Quinn TC. Direct detection of Chlamydia trachomatis in urine specimens from symptomatic and asymptomatic

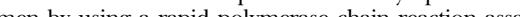
men by using a $1993 ; 31: 1209-1$

4 Østergaard L, Møller JK. Use of PCR and direct immuno-fluorescence microscopy for confirmation of results obtained by Syva MicroTrak Chlamydia enzyme immunoassay. J Clin Microbiol 1995;33:2620-3.

5 Østergaard L, Møller JK, Andersen B, Olesen F. Diagnosis of urogenital Chlamydia trachomatis infection in women based on mailed samples Chemel at home: multipractice comparative study. $B M J$ 1s

(Accepted 25 April 1997)

\title{
Opportunistic screening for chlamydial infection at time of cervical smear testing in general practice: prevalence study
}

\author{
Pippa Oakeshott, Sally Kerry, Sima Hay, Phillip Hay
}

Genital infection with Chlamydia trachomatis is the most common, curable sexually transmitted disease in England and Wales. ${ }^{1}$ In the United States and Sweden screening programmes have been shown to be effective in reducing the prevalence both of cervical infection with $C$ trachomatis and of sequelae such as pelvic inflammatory disease. ${ }^{12}$ In Britain a national selective screening programme has recently been recommended, ${ }^{3}$ but more data on the prevalence of chlamydial infection in different healthcare settings are needed. ${ }^{3}$ There have been no large studies of more than 1000 patients done on the patient populations from inner city general practices in the United Kingdom. ${ }^{1}$ The aim of this study was to determine the prevalence and predictors of chlamydial infection in women aged $<35$ having cervical smear tests in inner London general practices.

\section{Subjects, methods, and results}

Thirty seven practice nurses and 108 general practitioners from 30 practices participated in the study. The total patient population served by the practices was 192 000. The mean Jarman underprivileged area score was 23 (range 15-33). (A positive score indicates social deprivation and compares with a mean score for England and Wales of 0.) Twelve practices had only one or two practitioners.

Each practice was asked to recruit consecutive women aged $<35$ who were attending for a cervical smear test, record their clinical details, test them for chlamydia, and ask them to complete a confidential questionnaire on sexual health. Informed consent and ethical approval were obtained. Women who had taken antibiotics in the previous month were excluded.

Practice nurses and general practitioners were taught to take endocervical specimens for detection of chlamydial infection. These were analysed at St George's Hospital by enzyme immunoassay (Microtrak Syva II, Behring Diagnostics, Milton Keynes) and confirmed by direct fluorescent antibody testing. Six possible predictors of infection found in other studies were also examined: age $<25$, ethnic group, number of sexual partners, condom use, the presence of mucopurulent vaginal discharge, and the presence of a friable cervix with bleeding on contact.

Between May 1994 and October 1995, 1382 women aged 16-34 (mean age 27 ) were recruited. The mean number of subjects recruited from each practice was 46 (range 11-102). Practices were asked to complete recruitment rate forms for a sample of 25 consecutive women aged $<35$ attending for a cervical smear test. Practices recorded the age and ethnic origin of patients who were not asked to participate or who refused. Two practices had recruited 50 participants before the forms were introduced. Analysis of 18 forms returned by the practices showed that the age and ethnic origin of the $55 / 415$ (13\%) women who were not asked to participate and the $31 / 415(7 \%)$ who refused were similar to those patients who agreed to participate. Altogether, 1049 women $(76 \%)$ returned postal questionnaires. Of these women, 838/1040 $(80 \%)$ were white, $84 / 1040(8 \%)$ of Afro-Caribbean origin, 48/1040 (5\%) of black African origin, 29/1040 (3\%) of Indian subcontinent origin, and 41/1040 (4\%)
See p 350

Department of General Practice and Primary Care, St George's Hospital Medical School, London SW17 0RE Pippa Oakeshott, clinical lecturer Sally Kerry, statistician

Sima Hay, research assistant

Department of Genitourinary

Medicine, St George's Hospital Medical School

Phillip Hay, senior lecturer

Correspondence to: Dr Oakeshott oakeshot@sghms. ac.uk

BMJ 1998;316:351-2 
Table 1 Risk factors for chlamydial infection in 1049 women who returned postal questionnaires after visit to general practitioner for cervical smear test

\begin{tabular}{|c|c|c|c|c|c|c|}
\hline \multirow[b]{2}{*}{ Risk factor } & \multirow[b]{2}{*}{$\begin{array}{l}\text { No }(\%) \text { of } \\
\text { women with } \\
\text { risk factor }\end{array}$} & \multicolumn{2}{|c|}{ Prevalence (proportion) } & \multirow[b]{2}{*}{$\begin{array}{l}\text { Odds ratio } \\
(95 \% \mathrm{CI})\end{array}$} & \multirow[b]{2}{*}{$\begin{array}{l}\text { Adjusted odds ratio } \\
(95 \% \mathrm{Cl}) \dagger(\mathrm{n}=964)\end{array}$} & \multirow{2}{*}{$\begin{array}{l}\% \text { of positive } \\
\text { cases identified if } \\
\text { all women with } \\
\text { risk factor } \\
\text { screened }\end{array}$} \\
\hline & & $\begin{array}{l}\text { Among women } \\
\text { with risk factor }\end{array}$ & $\begin{array}{l}\text { Among women } \\
\text { without risk } \\
\text { factor }\end{array}$ & & & \\
\hline Age $<25(n=1049)$ & $283(27)$ & $6.0(17 / 283)$ & $2.1(16 / 766)$ & $3.0(1.5 \text { to } 6.0)^{\star \star}$ & $2.5(1.1 \text { to } 5.6)^{\star}$ & 52 \\
\hline Black ethnic origin $\neq(n=1040)$ & $132(13)$ & $9.1(12 / 132)$ & $2.3(21 / 908)$ & $4.2(2.0 \text { to } 8.8)^{\star \star \star}$ & $2.5(1.0 \text { to } 6.1)^{\star}$ & 37 \\
\hline Blackł and age <25 ( $\mathrm{n}=1040)$ & $38(4)$ & $21.0(8 / 38)$ & $2.5(25 / 1002)$ & $10.4(4.3 \text { to } 25.0)^{\star * *}$ & $4.8(1.6 \text { to } 14.2)^{\star *}$ & 24 \\
\hline Blackł or age $<25(n=1040)$ & $374(36)$ & $5.6(21 / 374)$ & $1.8(12 / 666)$ & $3.2(1.6 \text { to } 6.7)^{\star \star \star}$ & $2.7(1.2 \text { to } 6.0)^{\star}$ & 64 \\
\hline $\begin{array}{l}\text { Two or more sexual partners } \\
(n=1045)\end{array}$ & $224(21)$ & $7.1(16 / 224)$ & $1.9(16 / 821)$ & $3.9(1.9 \text { to } 7.9)^{\star \star *}$ & $3.5(1.6 \text { to } 7.7)^{\star *}$ & 50 \\
\hline $\begin{array}{l}\text { Condoms not always used } \\
(\mathrm{n}=988)\end{array}$ & $834(84)$ & $3.5(29 / 834)$ & $2.0(3 / 151)$ & $1.8(0.5$ to 6.0$)$ & $1.4(0.4$ to 5.0$)$ & 91 \\
\hline $\begin{array}{l}\text { Mucopurulent vaginal discharge } \\
(\mathrm{n}=1034)\end{array}$ & $197(19)$ & $6.6(13 / 197)$ & $2.2(18 / 837)$ & $3.2(1.6 \text { to } 6.7)^{\star \star}$ & $2.4(1.1 \text { to } 5.6)^{\star}$ & 42 \\
\hline Friable cervix $(n=1034)$ & $93(9)$ & $9.7(9 / 93)$ & $2.3(22 / 941)$ & $4.5(2.0 \text { to } 10.0)^{* * *}$ & $4.5(1.8 \text { to } 11.2)^{\star *}$ & 29 \\
\hline Black or age $<25$ or clinical & $532(52)$ & $5.1(27 / 532)$ & $0.8(4 / 493)$ & $6.5(2.3 \text { to } 18.8)^{\star \star *}$ & $5.6(1.9 \text { to } 16.2)^{\star *}$ & 87 \\
\hline
\end{tabular}

signs§ $(n=1025)$

${ }^{*} \mathrm{P}<0.05 ;{ }^{*} \mathrm{P}<0.01 ;{ }^{* *} \mathrm{P}<0.001$; †Adjusted for all other risk factors studied using multiple logistic regression; łlncludes both Afro-Caribbean and black African; $\S$ Mucopurulent vaginal discharge or friable cervix.

from other ethnic groups. Nine women did not provide information on their ethnic origin. This is similar to the ethnic profile of the borough of Wandsworth, where the study was conducted.

Forty of the 1382 women $(2.9 \%$; $95 \%$ confidence interval $2.0 \%$ to $3.8 \%$ ) tested positive for chlamydial infection. Infection was associated with age $<25$, being of black African or Afro Caribbean origin, having had two or more sexual partners in the previous year, the presence of mucopurulent vaginal discharge, and a friable cervix (table). Odds ratios remained significant after adjusting for all other risk factors studied using logistic regression. If all women aged $<25$ or of black race or with clinical signs had been screened, $52 \%$ of women would have had to be tested to detect $87 \%$ of cases.

\section{Comment}

The prevalence of chlamydial infection in our study was less than the $6 \%$ to $12 \%$ reported previously. ${ }^{1} \mathrm{Sev}$ eral factors might contribute to this. Enzyme immunoassays are used widely in general practice but have sensitivities of $60 \%$ to $80 \%$ when compared with optimal methods. ${ }^{14}$ Unlike the direct fluorescent antibody test, enzyme immunoassay does not permit assessment of the quality of endocervical sampling so we cannot tell how adequate the samples were. We excluded women who presented primarily with genitourinary symptoms. The prevalence of chlamydia in women attending general practices for smears may be lower than in those who do not attend or who use other facilities.

This study shows that routine testing for chlamydial infection is possible in a variety of non-research oriented, inner city practices. Screening by enzyme immunoassay may be cost effective at prevalences of $5 \%$ to $7 \%$ depending on what assumptions are made about the performance of the tests, the risk of complications, the effectiveness of treatment and contact tracing, and the costs. ${ }^{5}$ Information on age and ethnic group is easy to obtain; these are simple, pragmatic risk factors that can be evaluated without using complicated scoring systems. ${ }^{2}$ Since women aged $<25$ and black women seem more vulnerable to chlamydial infection, they could be offered testing when undergoing a speculum examination. Women with clinical signs should also be tested. ${ }^{1}$ Routinely asking about numbers of sexual partners is not realistic in general practice. Before undertaking a screening programme, a cost benefit analysis of screening for chlamydia in this population $^{1}$ and protocols for effective management of infected women are needed. ${ }^{3}$

We thank the patients, nurses, and general practitioners from based at the following health centres and surgeries in south London: Balham Health Centre; Balham Park Surgery; Bridge Lane Health Centre; Brocklebank Health Centre; Lavender Hill Group Practice; Tooting Bec Surgery; Triangle Surgery; Waterfall House; Winstanley Group Practice; 4 Ashvale Road; 7 Farrant House, Winstanley Road; 13-15 Barmouth Road; 14 Elsenham Street; 14 Queenstown Road; 17 Battersea Rise; 47 Boundaries Road; 51 Princes Road; 77 Thurleigh Road; 100 Falcon Rd; 119 Northcote Road; 127 Trinity Road; 219-221 Upper Tooting Road; 238 Mitcham Lane; 263 Lavender Hill; 298 Cavendish Road; and 464, 657, and 886 Garratt Lane.

Contributors: PO initiated, designed, and conducted the study; she also analysed data and wrote the paper. SK participated in designing the study, analysing the data, and writing the paper. SH and Diana Mason helped design and administer the questionnaire, collect and enter data, and manage the database. SH also participated in writing the paper. $\mathrm{PH}$ participated in designing the study, interpreting the data, and writing the paper. Professor S Hilton and Drs A Majeed, D Carrington, and I Simms commented on the paper. H Wong and S Sharpe organised the chlamydia tests. Dr J Popoola entered data. P Rink helped design the questionnaire. L-A Sallis provided secretarial support. PO and SK are guarantors for this paper.

Funding: This study was funded by the South Thames Project Grant Scheme.

Conflict of interest: None.

1 Public Health Laboratory Service Communicable Disease Surveillance Centre, HIV and STD Division. Genital Chlamydia trachomatis infection in England and Wales. London: PHLS, 1995.

2 Scholes D, Stergachis A, Heidrich F, Andrilla H, Holmes K, Stamm W. Prevention of pelvic inflammatory disease by screening for cervical chlamydia infection. $N$ Engl J Med 1996;334:1362-6.

3 Johnson A, Grun L, Haines A. Controlling genital chlamydia infection. BMJ 1996;313:1160-1.

4 Centers for Disease Control. Recommendations for the prevention and management of Chlamydia trachomatis infections, 1993. MMWR $1993 ; 42: 1-39$.

5 Phillips RS, Aronson MD, Taylor WC, Safran C. Should tests for Chlamydia trachomatis cervical infection be done during routine gynecologic visits? Ann Intern Med 1987;107:188-94

(Accepted 28 May 1997) 